\title{
Symbolic violence and the effort to silencing women in their positions as leaders (critics of the women leaders' habitus in advertising agencies)
}

\author{
Fitria Angeliqa $^{1 *}$, Billy K. Sarwono ${ }^{2}$ \\ ${ }^{1} \mathrm{Ph} . \mathrm{D}$. Candidate in Communication Science Department, Universitas Indonesia \\ ${ }^{2}$ Senior Lecturer in Communication Science Department, Universitas Indonesia
}

\begin{abstract}
The objective of this study perceives how the advertising agencies assign women to the position of the company leader as a patriarchal effort (as "the right hand" of the capitalists) to "muted" women in "comfortable" place. This research applies Pierre Bourdieu's Habitus-Field-Capital theory and its implications in the form of symbolic violence. This descriptive research applies constructivism paradigm. Obtained by conducting in-depth interviews with women leaders of advertising agencies, the data are examined using hermeneutic phenomenology. As a result, it becomes more and more difficult for female CEOs in advertising agencies--as a part of the media text producer--to recognize the acts of that violence. They rather duplicate and mimicking the symbolic violence in the texts they produce. Involving women in the agencies does not necessarily yield to the genderperspective texts as the automatic reflection of their thoughts, habits, and acts. It occurs because each social field is always full of subjective-contestation discourse which potentially generates dominating behaviors among the actors.
\end{abstract}

\section{Introduction}

As a media product, the advertisement cannot be studied solely from the distributional viewpoint. The role of the producer-referring to the advertising agency - in explaining the production mode and text is also very important, since it is related to the human aspect and the ideologies involved and reflected through the media content. In other words, the people working in the advertising agency are impossible to be separated from the organizational-structural position or from their background, which is very likely to influence texts in their social reality. This is where the subjectivity-objectivity dualism describing the dynamics of an individual's behavior appears. Belch and Belch $(2008$, p. 69) noted at least there are three stakeholders which are the most responsible in the field of advertising, namely the advertiser, advertising agency, and media, whose workflow is as follows:

\footnotetext{
* Corresponding author: fitria.angeliqa.17@gmail.com
} 


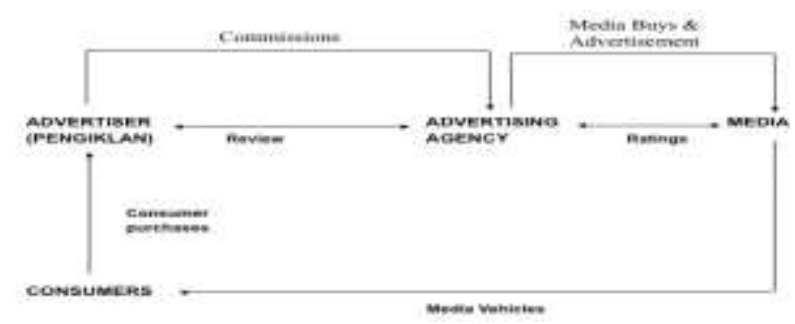

Fig. 1. The advertising industry process. Source: Processed by the researcher (2015), extracted from Belch \& Belch (2008, pp. 69-87)

The involvement of the advertiser will indeed firmly impose the business aspects of an advertising agency. Subsequently, the humanistic and individual creativity are often forgotten. This is where we hit a critical point; when the workers spend more time in the office (even on the weekends). Under the pretext of making their workers comfortable, the company practices the policy to legitimize their intervention to even the most private life of the workers. The public and private sphere are mixed-up in the name of modern company operationalization. To make it worse, the workers of advertising do not comprehend that it is the brand-new kind of exploitation.

At this point, the workers, as said by Bourdieu, are experiencing symbolic violence. However, since the victims "do not recognize" the violence, those practices seem to be normal and are rarely criticized. Generally speaking, symbolic violence is the violence whose victims "approve" the act of violence. Bourdieu argues the symbolic violence occurs in almost every aspect of society (Grenfell, Pierre Bourdieu-Key Concepts, 2008, p. 14). It is operating in "invisible" practices that are consisting metaphysical hierarchy.

Like other media products, the advertisement is also said to be predominated by the mainstream of men. The patriarchal discourse as the only narrative is trapping the advertisers, advertising workers, and even consumers. Nevertheless, hiring more female workers do not necessarily help to decrease the gender-bias in media content. Advertisements "creatively" portraying the double standard in women or women's sex appeal seem to be appropriate and are never criticized-the typical duplication occurring in patriarchal society. It happens for every illustration of advertisement forces consensus (Haryatmoko, 2016, p. 71).

For Chris Kramarae, the continuous exposure of the media which never stop portraying patriarchal discourse is a form of "shutting" women as the group of minority. The language of the media is the language of men which needs to be translated into that of women. Thanks to the prejudice of the inability of women to transform an equal conversation, which makes them a muted group (Griffin, 2006, p. 497). The stereotype opens the door for symbolic violence which is then benefited by men to build the structure in society, on which the women work.

As a matter of fact, in text producing, advertising agencies, according to Baudrillard in Haryatmoko (2016, p. 76) are mythic operators which present objects and events on stage after exaggerating them. What they exhibit is the simulation of reality, which then eventually becomes hyper-reality accommodating the interests of the advertisers. Nevertheless, in reality, the advertisement can simultaneously be the room to deconstruct ideologies (Williamson, 2007, p. 151), depending on how the advertising agency places the symbols representing the spirit of deconstruction. Therefore, it can be inferred that the advertising agencies are the agents which have an important and strategic position in placing either the real or extraordinarily-simulated symbols in the advertisement.

The depiction of reciprocal flow between the structure and the agent's patterned-behavior which becomes habits is an interesting topic for many scholars and becomes a focus in this research. Agent plays many roles and reflecting his/her habitus in many fields they enter. This research believes that there is a gap where the advertising agency workers should have the opportunity to practice ideological positioning or even deconstruction to reduce gender biases in advertisement texts. Especially for women leaders in the advertising agencies who have many kinds of capitals.

Producing texts as an effort to deconstruct the patriarchal narrative can be a form of the externalization of thoughts of the heterodox women advertising workers who equalize the gender of 
men and women in their fields. The ownership of significant economic, social, and cultural capital as a leader, namely the ability to determine the policy, might help to produce texts that are potential to eliminate or resist the patriarchal ideology, which might make them a non-frontal agent of change. What they show in their daily conducts can be the demonstration of their experience, even in their very unconscious acts. The meaning of every text she produces associating with herself as a modern woman possessing a high amount of economic, social, cultural capital, because of her education and her access to many public areas related to her habitus.

\section{Framework}

\subsection{Habitus-Field-Capital and the Potential of the Emergence of Symbolic Violence}

Habitus, Field, and Capital are the most famous theories of Pierre Bourdieu to explain human activities which, for him, cannot be generalized. Habitus becomes a system of thought, motivational structure, and even the ability to respond with the most proper action when facing every stimulus. Habitus occurs from the individual to group level, depending on how the intersubjective relation forms objectivation.

At times, an individual in a social structure will behave following the position and disposition one has ever got. It is when the orderliness is needed. Interestingly, it is not only the individual's consciousness which can "record" the orderliness but also the individual's body, which can be disciplined and made to remember what can and cannot be done. In other occasions, the body and the mind turn to be able to synergize facing other new structures encountered by the individual. It is partly triggered by the recorded process of learning and partly by spontaneous, improvised, and unconscious acts. When it happens, rules might be irrelevant because of the unpredicted time acceleration.

The presence of habitus cannot be separated from the other two concepts: field and capital. According to Bourdieu, the constitutive structure on an environment (such as in class society) generates a habitus, an almost permanent system, "contagious" dispositions, structured structure which also functions to structuring structure. Besides the sensitivity and the ability of an individual to respond to various events in their life, habitus also gives the orientation and inclination for one's actions unconsciously. Habitus guides an individual to play the "game" and prepares a set of corresponding acts. Here, habitus becomes the state of mind, the state of the body, and the state of being (Bourdieu, Language, and Symbolic Power, 1983, p. 13). The similar habitus adopted by many individuals in a group - which also becomes the construction of intersubjectivity-will transform into the dominant habitus.

Habitus works in the context of the field. Bourdieu sees that the actions in the arena are not the static reflection of the existing positions, yet as the results of various consensus to take positions (Bourdieu, 2007; Calhoun, Gerteis, Moody, Pfaff, \& Virk, 2009, p. 265). It means that a context is needed to make a habitus works. Therefore, habitus needs the support of the capital which corresponds with the context so that the individual can "fight" in the field. The strategy is the keyword. An individual can change the habitus fastly and show the most suitable capital to reach one's goal in the field. It is then obvious that habitus often becomes the unconscious rules of the individuals to conduct their life in society. Habitus works either consciously or unconsciously in an individual. Bourdieu likens it with athletes entering the stadium (Bourdieu in Webb, Schirato \& Danaher, 2002, p. 49).

Regarding the competition in the field, Bourdieu remarks about the rule of the game called doxa. It is the dominant understanding regarded as 'the rule' because of the objectivity practiced in the structure and the understanding of people in the field (Garnham, 1993, p. 179). Nevertheless, every field also accommodates many other habitus. Thus, it is not merely the problem of the contestation among habitus. Doxa which is regarded as the accomplice of capitalist ideology might as well repress one's habitus and rather affirm the dominant habitus, so the symbolic violence occurs with the legitimation of the company. Bourdieu also noted how capitalist practices also have their way in 
preserving their power through symbolic violence which penetrates to the social relation practices, which is more brutal and dehumanized, solely for the economic interests (Bourdieu, Outline of a Theory of Practice, 2013, p. 201).

Consequently, the field should be as social contexts which must be faced by the individual can be very tangible, yet it may as well be intangible. The strategy and skill to place the habitus will determine the individual's success in social relation-and one could even potentially dominate. When an individual puts her or his habitus mistakenly, one might be eliminated and must accept the more dominant habitus. It is why Bourdieu calls the field "champ," an arena full of the battle of habitus of the actors within.

Therefore, Bourdieu broadens the understanding of stratified class through four capitals: economic, cultural, social, and symbolic. Bourdieu sees that every field has the potential to create its structure because of the capital contestation and the ability/inability of people within it to post their capital and habitus. Because of the structure, classes grow in every field: bourgeois, petit-bourgeois, and popular (Bourdieu, Language and Symbolic Power, 1983, p. 30). For him, the intangible capital like cultural symbol is more potential in generating violence, compared to economic capital which can be easily converted.

Bourdieu regards capital as the "accumulation of history" (Calhoun, LiPuma, \& Postone, 1993, pp. 67-69). Bourdieu still sees as well as social and symbolic capital, play an important part in creating an individual's habitus. Capital is the social energy which only exists and bears fruit on the battlefield where it produces and reproduces. The cultural capital acts in the determination and the reproduction of social position.

\subsection{Gender and Patriarchy}

The easiest way to observe gender issue is through the practice of patriarchy which prevails in most of the countries around the world. Patriarchy is understood as a system of government where men control society through their positions as the head of the family (Weber, 1947 in Walby 1990, p. 27). As a result the other family members worship the head of the family, namely the father, who is believed in possessing the highest authority. Patriarchy is a socio-political system which places men in the dominant position, making them more superior in every aspect those who are regarded as "weak," particularly women. Therefore, men think that they are entitled to make rules for the "weak," and always preserve the domination through psychological terrors and violence (Hooks, 2016).

Weber in Walby (Theorizing Patriarchy (translated version), 1990, p. 27) illustrates the concept of patriarchy as a governmental system where men control society through their position as the head of the family. Viewed from this concept, it is natural then that symbolic violence is easier to legitimate in the name of marital institution/family. The norms of men are the most authoritative, whereas women "abide" the norms. Women's ideas are not at all put into consideration. And when women attempt to voice this inequality, the communication which is controlled by the masculinism tends to be unfavorable for women (Griffin, 2006, p. 497).

Patriarchy according to Bourdieu (2001) is a form of symbolic violence which is preserved by society. This concept is sublime in every context of life and is considered as normal practices, because it is legitimized by institutions such as family, marriage, religion, education, etc., even though it contains symbolic violence which perhaps is manifested in various forms. And as explained above, since the ruling norms are that of men, the structure of society "shut" women and leave them alone in their monotonous private life.

\section{Methodology}

The paradigm of this research is critical constructivism. The constructivist thinkers believe that there is no difference between mental and external world, which interprets relative, various, and complex. As well as the postmodernist paradigm, it also focuses on what happens "here" (not in 
another place). They believe that causality cannot be studied, in that for them human life is so complicated. Therefore, the valuation of research virtually does not have to represent the actual social condition (Newman, 2011, p. 118), but have to be returned to the research subject.

Thus, this research utilizes qualitative approach using the hermeneutic phenomenology of the data analysis. Qualitative research requires an in-depth interview to dig resources. The analytical units are women CEOs in the advertising agency. The experience of the informants in their work area becomes the main focus. The choosing of this kind of position is essential to show the economic, symbolic, and social capital they possess.

\section{Findings}

Demographically, the registration record of Indonesian Advertising Agency Association (P3I) informs as bellow;

Table 1. Women Leaders Proposition in Advertising Agency in Jakarta

\begin{tabular}{|c|c|c|c|}
\hline $\begin{array}{c}\text { Amount of Advertising Agency } \\
\text { in Jakarta }\end{array}$ & $\begin{array}{c}\text { Woman Top Leader in } \\
\text { Advertising in Jakarta }\end{array}$ & Percentage & $\begin{array}{c}\text { Responsible in } \\
\text { Text Production }\end{array}$ \\
\hline 151 & 31 & $21 \%$ & None \\
\hline
\end{tabular}

The table shows that there are only $21 \%$ or women in the highest position among 151 advertising agencies in Jakarta (P3I Pusat, 2015). There are no women in the strategic position in that is related to the production of media advertising texts. Almost all of the women leaders are in the positions related to the managerial.

Table 2. Description of Habitus-Field-Capital

\begin{tabular}{|c|c|c|c|}
\hline No. & 1st Informant & 2nd Informant & Information \\
\hline 1. & $\begin{array}{l}\text { Her father was hard in educating, } \\
\text { yet emphasizing good values in } \\
\text { life. Her mother was quiet, never } \\
\text { complained, demanded, and avoid } \\
\text { conflict, was always reliable for } \\
\text { any domestic problems. }\end{array}$ & $\begin{array}{l}\text { Her father rarely spoke, was } \\
\text { busy working and did not have } \\
\text { a close relationship with our } \\
\text { 2nd informant. The mother was } \\
\text { as a lecturer instead spent much } \\
\text { time with the informant. }\end{array}$ & $\begin{array}{l}\text { Initial habitus: The two } \\
\text { informants were under the } \\
\text { patriarchal ideology, which is } \\
\text { practiced by the father, yet is } \\
\text { maintained by the mother. }\end{array}$ \\
\hline 2. & $\begin{array}{l}\text { She has the habit of living } \\
\text { economically and always sharing } \\
\text { with her extended family because } \\
\text { of the limited resources. }\end{array}$ & $\begin{array}{l}\text { She rarely spent time going on } \\
\text { vacation with her family } \\
\text { because of their economic } \\
\text { limitation. }\end{array}$ & $\begin{array}{l}\text { Thoughts and habits which has } \\
\text { been adopted since they were } \\
\text { kids - the state of mind. }\end{array}$ \\
\hline 3. & $\begin{array}{l}\text { Competitive, independent, and } \\
\text { hard-working. In high school, she } \\
\text { also got used to being discipline. } \\
\text { She successfully got accepted at } \\
\text { the state university ironically } \\
\text { because she was afraid she } \\
\text { wouldn't be able to continue her } \\
\text { education after her father died. }\end{array}$ & $\begin{array}{l}\text { Competitive, independent, and } \\
\text { undoubtedly hard-working. She } \\
\text { was among the top five in } \\
\text { schools. In the university, she } \\
\text { became more focused on } \\
\text { reaching her dreams, namely to } \\
\text { be able to do all of the great } \\
\text { things. }\end{array}$ & $\begin{array}{l}\text { Advanced habitus: referring to } \\
\text { the role of high school, } \\
\text { forming the state of mind. The } \\
\text { discipline and competitive } \\
\text { educational atmosphere of the } \\
\text { school force the two } \\
\text { informants to "forge" } \\
\text { themselves even harder. }\end{array}$ \\
\hline 4. & $\begin{array}{l}\text { At the young age, she was } \\
\text { appointed as the General Manager. } \\
\text { Underestimated because she was } \\
\text { just a "little girl" instead motivated } \\
\text { her to reach the highest position. }\end{array}$ & $\begin{array}{l}\text { After graduation, she directly } \\
\text { worked at a digital company } \\
\text { which hadn't yet been noticed } \\
\text { by many people. }\end{array}$ & $\begin{array}{l}\text { Advanced habitus: early days } \\
\text { or working. Illustrating the } \\
\text { disposition accepted in the } \\
\text { initial habitus; the unyielding } \\
\text { nature and the focus towards } \\
\text { objectives. }\end{array}$ \\
\hline 5 & $\begin{array}{l}\text { She admits that she is strict and } \\
\text { stern to her subordinates --a } \\
\text { character, which, is opposite to her } \\
\text { husband's (patient, and not } \\
\text { demanding). She did significant } \\
\text { organizing. The policy of the }\end{array}$ & $\begin{array}{l}\text { Before deciding something, she } \\
\text { is more likely to discuss with } \\
\text { the partner (male) and her } \\
\text { employees to apply various } \\
\text { policies: giving furlough in } \\
\text { some special days; One month }\end{array}$ & $\begin{array}{l}\text { Advanced habitus: The 1st } \\
\text { informant, which has already } \\
\text { married does not do } \\
\text { breakthrough in the company's } \\
\text { rules. The 2nd informant } \\
\text { formulated "woman-friendly" }\end{array}$ \\
\hline
\end{tabular}




\begin{tabular}{|l|l|l|l|}
\hline & $\begin{array}{l}\text { company still adopts the necessary } \\
\text { standards. }\end{array}$ & $\begin{array}{l}\text { paternity leaves with work } \\
\text { remotely; providing nursing } \\
\text { room in the office. }\end{array}$ & $\begin{array}{l}\text { company rules, though she still } \\
\text { puts "work" terminology on } \\
\text { her policies. }\end{array}$ \\
\hline 6 & $\begin{array}{l}\text { She is more responsible for the } \\
\text { company' managerial and } \\
\text { operational aspect. She chooses not } \\
\text { to interfere with the creative } \\
\text { division which is headed by her } \\
\text { husband. }\end{array}$ & $\begin{array}{l}\text { She focuses on the development } \\
\text { of human resource which is } \\
\text { conducted simultaneously with } \\
\text { the business development. }\end{array}$ & $\begin{array}{l}\text { Both are responsible for } \\
\text { managerial and human } \\
\text { resource, rather than in the } \\
\text { production of advertisement } \\
\text { text. }\end{array}$ \\
\hline 7 & $\begin{array}{l}\text { For her, advertising has } \\
\text { "accommodated" women interests, } \\
\text { and there are many women become } \\
\text { leaders in this industry. }\end{array}$ & $\begin{array}{l}\text { For her, advertising is no longer } \\
\text { patriarchal. }\end{array}$ & $\begin{array}{l}\text { They are sure that there is no } \\
\text { "women issue" in the } \\
\text { advertising industry or the text } \\
\text { produced by the agencies. }\end{array}$ \\
\hline 8. & $\begin{array}{l}\text { She never practices the division of } \\
\text { labor to her children. She also very } \\
\text { considerate with her husband, } \\
\text { whom as patient and rarely tense. }\end{array}$ & $\begin{array}{l}\text { As the oldest child, she feels } \\
\text { responsible for taking care of } \\
\text { her father. }\end{array}$ & $\begin{array}{l}\text { The two informants are } \\
\text { showing the incapability of } \\
\text { negotiating her habitus with } \\
\text { male. }\end{array}$ \\
\hline
\end{tabular}

\section{Discussion and conclusion}

The findings show that the two informants come from a simple family, with a stern (father's) educational method. The financial limitations during childhood had inspired them to achieve great things when they have grown up. The two informants are both woman CEO in an advertising agency who work abreast with a male partner. Since they were kids, they have been used to the confinement of patriarchal ideology, so it is surely not easy for them to "escape" from childhood doxas in the fields they encounter when they are adult. For the reason that their position is above the managerial level, they have several capitals, including: first, economic capital indicated by the high income; second, cultural capital indicated by the high level of education and-legitimized bypositions they have; third, the ownership of social capital which can be represented through the networks of friends or association/communities they join; and fourth, the symbolic capital, referring to valuable things which is in accordance with their income.

It turns that having sufficient amounts of economic and cultural capital doesn't automatically result in the implementation of symbolic capital acknowledged by the institution. Therefore, though a woman is in a high position, the "authority" is very likely to be "set" in such way that rather affirms the patriarchal practices, yet the practices are not recognized as a form of gender inequality. Positioning women at the leadership level might be one of the ways of the management to "sustain" the company, using the new kind of exploitation which is unrealized by the actors. As a result the habitus presented by women could only be a means to "play safe" because of their miscomprehension of the hidden practice of dominations. It indicates that there is no sufficient relevancy between ad text and the reality of the creative process.

The high position in the company structure has put them in the petit-bourgeois class, which is most likely unable to recognize violence and exploitation over themselves. This group, by Bourdieu, is said to be the "most victimized" by the practices of symbolic violence (Bourdieu, The Social Structure of The Economy, 2005, p. 185). They are the class which is trapped by their social status and let the dominant class conduct the simultaneous symbolic violence, so long as they can still be the petit-bourgeois. Since the beginning, the reflexive behavior of the petit-bourgeois makes them unconscious over the existence of the symbolic violence, which eventually produces permanent banality. In the end, the petit-bourgeois also duplicates the identical violence and applies them to their subordinates, as normal, unprotested conduct.

Finally, the incomprehension of women over their position in petit-bourgeois class may confuse the context, which might drag them to the unrealized practices of exploitations. The strong relationship with the dominant group is, because the petit-bourgeoisie do not have a different standpoint. However, the duplication to the higher class is one of the strategies of the petitbourgeoisie to prevent from being thrown away from the field. Instead of making a change, the 
habitus of women leader may as well be a "fake" one because of the much stronger capitalist disposition in every field on which they compete.

Here, it is obvious how the banality becomes the implication of subjective-objective dualism in Bourdieu's concept of habitus. The inability to separate the objective and subjective thought eventually "cage" women in the dominant habitus, which has been preserved in the so-called "normal" dispositions. Therefore, the effort to resist the grand narrative of patriarchy becomes a naivety since patriarchy is the "right hand" of the capitalist in sustaining its authority. Nevertheless, "smuggling" it into seemingly natural texts in daily social practice eventually resulting in the visualization of advertising is the most relevant strategy if they have already "recognized" the practices of symbolic violence.

\section{Acknowledgements}

This Work is supported by Hibah PITTA 2018 funded by DRPM Universitas Indonesia No. 5000/UN2.R3.1/HKP.05.00/2018.

\section{Reference}

1. Belch, G. E., \& Belch, M. E. (2003). Advertising and Promotion: Integrated Marketing Communication, 6th edition. McGrawHill.

2. Bourdieu, P. (1983). Language and Symbolic Power. Cambridge, Massachusetts: Harvard University Press.

3. . (2001). Masculine Domination. California: Standford University Press.

4. (2005). The Social Structure of The Economy. Cambridge: Polity Press.

$5 . \quad$ (2013). Outline of a Theory of Practice. Cambridge: Cambridge University Press.

6. Calhoun, C., LiPuma, E., \& Postone, M. (1993). Bourdieu: Critical Perspective. Chicago: The University of Chicago Press.

7. Calhoun, C., Gerteis, J., Moody, J., Pfaff, S., \& Virk, I. (2009). Contemporary Sociological Theory 2nd Edition. USA: Blackwell Publishing.

8. Garnham, N. (1993). Bourdieu, the Cultural Arbitraty, and Television. In C. Calhoun, E. LiPuma, \& M. Postone, Bourdieu, Critical Perspectve. Chicago: The University of Chicago Press.

9. Grenfell, M. (2008). Pierre Bourdieu-Key Concepts. UK: Acumen Publishing.

10. Griffin, E. M. (2006). A Firts Look of Communication Theory 6th Edition. Singapore: McGrawHill.

11. Haryatmoko. (2016). Membongkar Rezim Kepastian: Pemikiran Kritis Post-Strukturalis. Yogyakarta: Kanisius.

12. Newman, W. L. (2011). Social Research Methods: Qualitative and Quantitative Approach. Boston: Allyn \& Bacon.

13. Walby, S. (1990). Teorisasi Patriarki (terjemahan). Yogyakarta: Jalasutra.

14. Webb, J., Schirato, T., \& Danaher, G. (2002). Understanding Bourdieu. Australia: Allen \& Unwin.

15. Hooks, B. (2016). Louisvile Anarchist Federation. Retrieved May 17, 2016, from htp://LAFFexperiment.org: http://imaginenoborders.org/pdf/zines/UnderstandingPatriarchy.pdf

16. Yodi, A. S. (2013, January 13). iesdepedia. Retrieved May 22, 2013, from http://iesdepedia.com/blog/2013/01/12/habitus/: http://iesdepedia.com 